\title{
Investigation of the local Ge concentration in Si/SiGe nanostructures by convergent- beam electron diffraction
}

Doctoral Thesis

Author(s):

Ruh, Elisabeth Margrit

Publication date:

2008

Permanent link:

https://doi.org/10.3929/ethz-a-005750047

Rights / license:

In Copyright - Non-Commercial Use Permitted 
Diss. ETH No. 17908

\title{
Investigation of the Local Ge Concentration in $\mathrm{Si} / \mathrm{SiGe}$ Nanostructures by Convergent-Beam Electron Diffraction
}

\author{
A dissertation submitted to the \\ ETH ZURICH \\ for the degree of \\ Doctor of Sciences
}

presented by

Elisabeth Margrit Ruh

Dipl. Phys. ETH

born December 13, 1977

citizen of Schaffhausen (SH) and Buch (SH)

accepted on the recommendation of:

Prof. Dr. Klaus Ensslin, examiner

Prof. Dr. Detlev Grützmacher, co-examiner

Dr. Elisabeth Müller Gubler, co-examiner

June 2008 


\section{Abstract}

In this thesis detailed investigations of the local Ge concentration in nanostructured SiGe materials by convergent-beam electron diffraction (CBED) analyses and finite element method (FEM) calculations are presented. The aim of the studies was to reach high spatial resolution for the determination of the local lattice parameters and the Ge concentration in order to develop a novel way to analyze semiconductor nanostructures on an atomic scale. The strain conditions in these structures and especially the configuration at their interfaces were accurately characterized. A further aim of this work was to contribute with the thereby obtained knowledge about nanostructured SiGe materials to the research and development of future nano-electronic SiGe devices.

In the mode of scanning transmission electron microscopy (STEM) series of zeroloss filtered, bright-field CBED patterns were taken in the form of a line scan across the nano-structures using the [3 40]-zone axis. The higher order Laue zone (HOLZ) lines in each of these measured CBED patterns were fitted with the JEMS program (Java electron microscopy software, P. Stadelmann, EPFL, Switzerland) in order to deduce the local lattice parameters. Thus, information about the three-dimensional crystal structure was extracted from nanometer-sized regions. The changes of positions of these HOLZ lines were investigated in detail with the JEMS program in order to confirm their unambiguity with respect to the lattice constants.

With the finite element method the strain conditions in all three spatial directions of thin TEM samples were calculated taking elastic relaxation into account. The influence of strain and strain relaxation on the TEM sample, i.e. the deformation of the crystal lattice, was studied and the dependence of the HOLZ lines on these deformations was discussed. Furthermore the elasticity theory was used to describe the relation between the lattice parameters and the Ge concentration by means of a definite equation. Thus, the Ge concentration corresponding to certain lattice parameters obtained from the experimental CBED patterns could be deduced unambiguously.

In order to ascertain the influence of size and shape of the focused electron beam on the measured data, a series of CBED patterns was taken across the interface between $\mathrm{Si}$ and AlN which is known to be very abrupt. The appearance and the change of position of the CBED disks were investigated in detail in order to estimate the spatial resolution of the CBED method. 


\section{Zusammenfassung}

In dieser Doktorarbeit werden detaillierte Untersuchungen der lokalen Ge-Konzentration in nanostrukturierten SiGe-Materialien mit konvergenter Elektronenbeugung (CBED) und Finite-Elemente-Rechnung präsentiert. Das Ziel dieser Studien war es, eine hohe Ortsauflösung für die Bestimmung der lokalen Gitterparameter und der Ge-Konzentration zu erhalten, um eine neue Untersuchungs-Methode auf atomarem Massstab für Halbleiter-Nanostrukturen zu entwickeln. Die Spannungszustände in diesen Strukturen und speziell die Beschaffenheit an den Grenzflächen wurden genau charakterisiert. Ein weiteres Ziel dieser Arbeit war es, mit diesen Erkenntnissen über nanostrukturierte SiGe-Materialien einen Beitrag zur Erforschung und Entwicklung von zukünftigen nanoelektronischen SiGe-Bauelementen zu leisten.

Im Modus der Raster-Transmissionselektronenmikroskopie (STEM) wurden Serien von gefilterten, verlustfreien Hellfeld CBED-Bildern in Form eines Linien-Scans quer über die Nanostrukturen aufgenommen, wobei die [3 40$]$-Zonenachsen-Orientierung verwendet wurde. Die Linien der Laue-Zonen höherer Ordnung (HOLZ Linien) jedes gemessenen CBED-Bildes wurden mit dem JEMS-Programm (Java electron microscopy software, P. Stadelmann, ETH Lausanne, Schweiz) gefittet, um die lokalen Gitterkonstanten zu bestimmen. Somit wurden Informationen über die dreidimensionale Kristallstruktur aus nanometergrossen Regionen gewonnen. Die Positionsänderungen dieser HOLZ Linien wurden detailliert mit dem JEMS-Programm untersucht, um deren Eindeutigkeit in Bezug auf die Gitterkonstanten zu bestätigen.

Mit der Methode der Finite-Elemente wurden die Spannungszustände in allen drei Raumrichtungen einer dünnen TEM Probe berechnet, wobei die elastische Entspannung berücksichtigt wurde. Dabei wurde der Einfluss der Verspannung und der Entspannung auf die TEM Probe, d.h. die Verformung des Kristallgitters, genau untersucht und die Abhängigkeit der HOLZ Linien von diesen Verformungen diskutiert. Zudem wurde die Elastizitätstheorie verwendet, um die Beziehung zwischen den Gitterparametern und der Ge-Konzentration mit einer exakten Gleichung zu beschreiben. Somit konnte die zu den experimentell erhaltenen Gitterparametern dazu gehörende Ge-Konzentration eindeutig abgeleitet werden.

Um den Einfluss der Grösse und Form des fokussierten Elektronenstrahls auf die gemessenen Daten zu ermitteln, wurde eine Serie von CBED-Bildern quer über die Grenzfläche zwischen Si und AlN, die als sehr abrupt gilt, aufgenommen. Das Aussehen und die Änderungen der Positionen der CBED Scheiben wurden detailliert studiert, um die räumliche Auflösung der CBED-Methode abzuschätzen. 